\title{
Dimensions of diet segregation in grey seals Halichoerus grypus revealed through stable isotopes of carbon $\left(\delta^{13} \mathrm{C}\right)$ and nitrogen $\left(\delta^{15} \mathrm{~N}\right)$
}

\author{
Strahan Tucker $^{1, *}$, W. Don Bowen ${ }^{2}$, Sara J. Iverson ${ }^{1}$ \\ ${ }^{1}$ Department of Biology, Dalhousie University, Halifax, Nova Scotia, Canada \\ ${ }^{2}$ Marine Fish Division, Bedford Institute of Oceanography, Department of Fisheries and Oceans, \\ Dartmouth, Nova Scotia, Canada
}

\begin{abstract}
Although many studies have documented diets for terrestrial mammals, much less is known about prey selection in marine mammals. Variation in body size of terrestrial carnivores is correlated with mass of prey consumed, and predator size often determines dietary overlap. Grey seals Halichoerus grypus are a size-dimorphic phocid seal inhabiting the Northwest Atlantic, with males $1.5 \times$ larger than females. Stable isotopes of carbon $\left(\delta^{13} \mathrm{C}\right)$ and nitrogen $\left(\delta^{15} \mathrm{~N}\right)$ provide useful tools for estimating trophic positions and carbon flow to consumers in food webs. $\delta^{13} \mathrm{C}$ and $\delta^{15} \mathrm{~N}$ were analyzed for individual adult grey seals from Sable Island, Canada, between 1996 and 2001. Samples of skin were taken in May or September and the same animals were re-sampled when they returned to the breeding colony in January. In addition, samples were taken from juveniles $(n=29)$ in January 2004. $\delta^{13} \mathrm{C}$ and $\delta^{15} \mathrm{~N}$ were also analyzed for 12 fish and 3 invertebrate species from the Scotian Shelf. Adult male $(\mathrm{n}=36)$ and female $(\mathrm{n}=36)$ grey seals exhibited significantly different $\delta^{13} \mathrm{C}$ and $\delta^{15} \mathrm{~N}$ values $\left(F_{1,70}=22.40 ; \mathrm{p}<0.001\right)$. On average, males were more enriched in both $\delta^{13} \mathrm{C}$ and $\delta^{15} \mathrm{~N}$ than females. While there were no differences between sex in juveniles, signatures were significantly different from adults $\left(F_{2,101}=28.05 ; \mathrm{p}<0.001\right)$. Comparison of isotope values from potential prey suggests that adult males feed more heavily on benthic prey, whereas adult females appear to feed more on pelagic prey. Juveniles also appear to feed more on pelagic prey. These results are consistent with known differences in dive patterns and foraging behaviour in this population. In addition, there was a positive effect of body size on both $\delta^{13} \mathrm{C}(t=2.54, \mathrm{p}=0.014)$ and $\delta^{15} \mathrm{~N}(t=2.48, \mathrm{p}=0.016)$ and a positive relationship between $\delta^{15} \mathrm{~N}$ and the rate of fat accumulation $\left(\mathrm{kg} \mathrm{d}^{-1}\right)$. These results suggest an underlying energetic basis to diet variation in grey seals. Finally, examination of the variance in stable isotope ratios suggested that while individual grey seals appear to be relative specialists in their diet, niche breadth was $1.5 \times$ greater in males than in females. On average, adult grey seals had a $2 \times$ higher niche breadth than juveniles.
\end{abstract}

KEY WORDS: Grey seal · Sexual size dimorphism $\cdot$ Diet segregation $\cdot$ Stable isotopes $\cdot$ Ontogeny Energetics

Resale or republication not permitted without written consent of the publisher

\section{INTRODUCTION}

Vertebrate diets are influenced by factors intrinsic to the organism and by extrinsic or ecological factors. Body size is thought to be a crucial determinant of food web patterns and processes (Chase 1999, Memmott et al. 2000, Williams \& Martinez 2000). An increase in predator size is associated with an increase in both mean prey size (Carbone et al. 1999, Radloff \& du Toit 2004) and prey diversity (Gittleman 1985, Cohen et al.
1993). It is hypothesized that larger predators consume larger prey items to satisfy greater absolute energy requirements. Moreover, predator size generally determines inter-specific dietary overlap (Sinclair et al. 2003), as ontogenetic shifts in diet often outweigh the variation in diets across similarly sized species (Woodward \& Hildrew 2002). Among terrestrial vertebrate carnivores, with body sizes spanning more than 3 orders of magnitude, body size influences not only relative prey size but also the type of prey eaten. For ex- 
ample, small terrestrial carnivores consume an omnivorous diet (plant, invertebrate and vertebrate) whereas large predators consume a diet comprised primarily of vertebrate prey (Carbone et al. 1999). This switch in diet is concurrent with a change in mean prey size that exceeds predator mass. The transition to an exclusive carnivorous diet with increasing body size is thought to reflect a simple energetic constraint: the inability to sustain body size based on relatively smaller and lower quality prey. Thus, for terrestrial carnivores, body size appears to influence both the prey size and the type of prey that can be consumed in order to satisfy energy requirements.

In contrast, a correlation between predator body size and prey size is not as apparent among upper-trophic level marine carnivores, as most species consume prey smaller than themselves, often by several orders of magnitude. However, within size-dimorphic predators, the larger sex often consumes larger prey items, or alternatively, the sexes have different diets altogether (reviewed in Bowen et al. 2002). There is mounting evidence for sex differences in the foraging behaviour of size-dimorphic marine mammals, where males are significantly larger than females (Le Boeuf et al. 1993, 2000, Beck et al. 2003a, b, Field et al. 2005, Breed et al. 2006). Differential resource use by the sexes, observed in both size-dimorphic (e.g. Clarke et al. 1998) and monomorphic (e.g. Lewis et al. 2002) species, may also be due to variation in the sex-specific costs of reproduction (Ginnett \& Demment 1997). Ontogenetic diet shifts are thought to result from differing energetic costs associated either with body size or learning (Estes et al. 2003).

There is also increasing recognition of the relatively high degree of individual variation in foraging behaviour and diet among marine carnivores (e.g. Bolnick et al. 2003, Estes et al. 2003, Austin et al. 2004, 2006a). This is in contrast to the idea of a population level optimal diet (Sih \& Christensen 2001). Intra-specific variation in diet that cannot be explained by intrinsic factors has been documented in insects, fishes, reptiles, birds, ungulates and mammals (reviewed in Bolnick et al. 2003 and Estes et al. 2003).

Despite the importance of understanding predator diets, the methods used to estimate diet are often subject to considerable bias (Bowen \& Siniff 1999). However, stable isotopes of carbon $\left({ }^{13} \mathrm{C} /{ }^{12} \mathrm{C} ; \delta^{13} \mathrm{C}\right)$ and nitrogen $\left({ }^{15} \mathrm{~N} /{ }^{14} \mathrm{~N} ; \delta^{15} \mathrm{~N}\right)$ have proven to be useful tools for estimating trophic positions of, and carbon flow to, consumers in food webs (Post 2002). Isotopes of carbon are enriched in consumers relative to diet by $<1 \%$, and are more indicative of carbon source or habitat than trophic level. By contrast, nitrogen isotopes are enriched by an average of 3 to $5 \%$ o (Hobson \& Welch 1992, Hobson et al.1994) thereby providing a measure of trophic posi- tion. In marine systems, a benthic-pelagic continuum has been identified with $\delta^{13} \mathrm{C}$ increasing from negative (depleted) values for pelagic species to more positive (enriched) values for benthic species, and $\delta^{15} \mathrm{~N}$ increases with trophic level within each system respectively (Davenport \& Bax 2002, Sherwood \& Rose 2005). Isotope signatures of consumers represent the assimilated portion of diet integrated over periods of weeks to months (Hobson et al. 1996, Kurle \& Worthy 2001, Lesage et al. 2001). Taken together, $\delta^{15} \mathrm{~N}$ and $\delta^{13} \mathrm{C}$ provide a 2-dimensional, standardized estimate of the dietary space occupied by a predator relative to other consumers and prey in an ecosystem. Thus, stable isotopes indicate trophic relationships related to functional patterns of feeding rather than taxonomic relationships (Davenport \& Bax 2002). Recently, Bearhop et al. (2004) suggested using stable isotope ratios to estimate dietary niche breadth by examining the variance within and between populations of consumers. This approach provides a practical measure of trophic niche breadth since it is relatively simple to obtain and stable isotopes integrate diet, both prey diversity and evenness, over an ecologically meaningful time-scale.

Grey seals Halichoerus grypus are a size-dimorphic phocid species, with males $1.5 \times$ heavier than females. Recent studies have indicated sex differences in adult foraging behaviour at the level of individual dives and seasonal habitat use (Beck et al. 2003b, Austin et al. 2006b, Breed et al. 2006). Males dive deeper with more flat bottom-shaped dives potentially indicative of benthic foraging, whereas females dive longer, and tend to display strong diurnal patterns in depth of diving suggestive of pelagic foraging. Adult males and females also differ in their seasonal patterns of energy storage and expenditure (Beck et al. 2003a). As in other phocid seals, dive capacity of grey seals in their first year of life is constrained by their physiology (Noren et al. 2005). Thus, relative to adults, juveniles presumably have poorer foraging ability and may have access to fewer or different types of prey than adults. (e.g. Baker \& Donohue 2000, Noren et al. 2005). These differences in foraging suggest that diets may vary between the sexes and that this variation may have an ontogenetic component.

Our objectives were to test for benthic-pelagic segregation in diets among adults as indicated by sex differences in diving behaviour, to determine whether sex differences in diet are evident among relatively naïve and physiologically less competent foragers, to investigate within-sex effects of body size on isotope signatures and to compare population and individual variability in dietary niche breadth over time. We also sought to determine the relationship between stable isotope-inferred diet and the rate of energy storage in grey seals. 


\section{MATERIALS AND METHODS}

Grey seal sampling. The study was conducted, from 1996 to 2001 on Sable Island $\left(43^{\circ} 55^{\prime} \mathrm{N}, 60^{\circ} 00^{\prime} \mathrm{W}\right)$, a vegetated sandbar ca. $45 \mathrm{~km}$ long, about $300 \mathrm{~km} \mathrm{SE}$ of mainland Nova Scotia, Canada. Seals breed on the island in January, return to moult in spring, and haul out on the Island periodically at other times of the year (Beck et al. 2003a). Individuals were captured onshore using hand-held nets (see Bowen et al. 1992) and most animals were weighed to the nearest $0.5 \mathrm{~kg}$. Skin samples (ca. 0.05 to $0.1 \mathrm{~g}$ ) were taken from the rear flipper of known-aged adult male $(\mathrm{n}=36)$ and female $(\mathrm{n}=36)$ grey seals in May-June or September-October and the same animals were re-sampled in January at the start of the breeding season. Twenty-nine juveniles (mostly yearlings; 14 male, 15 female) were sampled in January 2004. Lipids were extracted from skin samples using a modified Folch method (Iverson et al. 2001) and the rest of the sample analyzed for stable isotopes of carbon and nitrogen. Total body fat content was determined in a sub-sample of these adults using hydrogen isotope dilution (Beck et al. 2003a, D. Austin unpubl.). Mass gains $\left(\mathrm{kg} \mathrm{d}^{-1}\right)$ were calculated as the change in total mass $(\mathrm{kg})$ between sampling times (initial capture date in spring or fall and recapture date in winter), divided by the sampling interval (d). Similarly, fat accumulation rates $\left(\mathrm{kg}_{\mathrm{fat}} \mathrm{d}^{-1}\right)$ were calculated as the change in fat content $\left(\mathrm{kg}_{\text {fat }}\right)$ between sampling times divided by the sampling interval.

Fish and invertebrate prey sampling. Fishes and invertebrates were collected and frozen during stratified, random, bottom-trawl surveys conducted in the summer on the Scotian Shelf (Northwest Atlantic Fisheries Organization sub areas $4 \mathrm{~V}, 4 \mathrm{~W}$, and $4 \mathrm{X}$ ) in 2000 and 2001 (see Budge et al. 2001). Three individuals each of 12 fish and 3 invertebrate species were thawed and fork length or carapace width was measured to the nearest $0.1 \mathrm{~cm}$ and body mass measured to the nearest $0.1 \mathrm{~g}$. Each individual was then homogenized. Lipids were quantitatively recovered in duplicate from subsamples (ca. $1.5 \mathrm{~g}$ ) of the homogenized tissue using the modified Folch method as above (data contained in Budge et al. 2001). An additional sub-sample (ca. $1.5 \mathrm{~g}$ ) was subsequently analyzed for stable isotopes of carbon and nitrogen. Fishes and invertebrates were classified as pelagic or benthic based on previous knowledge of feeding habits (Scott \& Scott 1988, Sherwood $\&$ Rose 2005). For some analyses, we expanded our dataset by using stable isotope values from the Gulf of St Laurence (Lesage et al. 2001) and the southern Grand Banks (Sherwood \& Rose 2005) because our sample of prey and invertebrates represents only a sub-sample of potential prey on the Scotian Shelf. Both areas are part of the foraging range of NW Atlantic grey seals (Bowen et al. 2006). Since the samples of Lesage et al. (2001) were lipid extracted prior to stable isotope analysis, we standardized our data and the data from Sherwood \& Rose (2005) so that all data were directly comparable. Lipid-normalized values of $\delta^{13} \mathrm{C}$ were calculated from reported $\mathrm{C}: \mathrm{N}$ ratios using the equations in McConnaughey \& McRoy (1979).

Stable isotope analysis. Seal, fish and invertebrate samples were dried to constant weight (for $48 \mathrm{~h}$ at $80^{\circ} \mathrm{C}$ in a drying oven) and crushed to a fine powder using a mortar and pestle. Stable carbon and nitrogen isotope ratios of these samples were determined by the analysis of $\mathrm{CO}_{2}$ and $\mathrm{N}_{2}$ produced by combustion in a $\mathrm{CE}$ Elemental Analyzer followed by gas chromatograph separation and analysis with a Delta plus isotope ratio mass spectrometer (G. G. Hatch Isotope Laboratories, University of Ottawa, Ontario, Canada). Stable carbon and nitrogen ratios were expressed in delta $(\delta)$ notation, defined as the parts per thousand $(\%)$ deviation from a standard material: $\delta^{13} \mathrm{C}$ or $\delta^{15} \mathrm{~N}=\left(\left[R_{\text {sample }}\right)\right.$ $\left.\left.R_{\text {standard }}\right]-1\right) \times 1000 ; R={ }^{13} \mathrm{C} /{ }^{12} \mathrm{C}$ or ${ }^{15} \mathrm{~N} /{ }^{14} \mathrm{~N}$ ). Standards used were PDB limestone for $\delta^{13} \mathrm{C}$ and $\mathrm{N}_{2}$ in air for $\delta^{15} \mathrm{~N}$. A sub-sample $(8 \%)$ was analyzed in duplicate; the average standard error of the mean for replicates was $0.15 \%$ for $\delta^{13} \mathrm{C}$ and $0.18 \%$ for $\delta^{15} \mathrm{~N}$. Total carbon and nitrogen of samples was measured simultaneously during stable isotope analysis (G. G. Hatch Isotope Laboratories). C:N ratios are considered a relatively good surrogate for tissue lipid content (i.e. higher lipid samples have higher C:N ratios; Tieszen et al. 1983). $\delta^{13} \mathrm{C}$ values of skin in pinnipeds is known to fractionate by $2.8 \%$ over prey (Hobson et al. 1996, Kurle \& Worthy 2001). Therefore, when comparing seal to potential prey, $\delta^{13} \mathrm{C}$ values for seal skin were corrected for the known fractionation of the tissue.

Statistical analysis. We developed Generalised Linear Models (GLMs) with Gaussian error distributions using our data and the expanded dataset of Lesage et al. (2001) and Sherwood \& Rose (2005) in order to address the following questions: Do stable isotope signatures vary between trophic guilds (pelagic or benthic) of fishes and invertebrates? Is the $\mathrm{C}: \mathrm{N}$ ratio a suitable proxy for prey lipid content? Does lipid content ( $\mathrm{C}: \mathrm{N}$ ratio) vary among trophic groups of fish and invertebrates?

Grey seals are wide-ranging predators, but there is some evidence that those sampled in the fall may use somewhat different areas to those sampled in the spring (Austin et al. 2004, Breed et al. 2006). Furthermore, some prey species eaten by grey seals also exhibit seasonal variation in distribution and abundance (Bowen et al. 2006). We ran a GLM on cross-sectional data to jointly test for the effects of initial sampling period (spring vs. fall) and sex on the stable isotope values at recapture (January). First, we tested for an effect of sex on stable isotope values at recapture within each sampling period 
and secondly, we compared males and females, respectively, between the 2 sampling periods.

We used our longitudinal data on each adult to test for the effects of sex, body size, and season on stable isotope values, using Repeated-Measures Generalised Linear Models (RM GLMs). As prey differ in energy content, using GLMs we tested whether isotope values (our proxy for diet) had an effect on the rate of energy accumulation $\left(\mathrm{kg}_{\text {fat }} \mathrm{d}^{-1}\right)$ and overall energy content (\%fat) of seals. Since the highest rate of fat accumulation for both sexes occurs in the fall (Beck et al. 2003a), we used the fall sampled animals to test this hypothesis. We also ran a GLM to test for differences in diet with age, by comparing winter stable isotope values of adults and juveniles. To examine temporal changes in diet and the effects of sex, sampling season and mass gain on the change in isotope signatures, we ran a GLM on the difference between the final and initial $\delta^{13} \mathrm{C}$ and $\delta^{15} \mathrm{~N}$ values for each adult. We had insufficient samples to examine interannual effects.

We examined the relative dietary niche breadth of grey seals by estimating the relative range of prey species consumed by juveniles and adults, where a wider niche breadth should be reflected in a larger variance of isotope signatures (Bearhop et al. 2004). We also examined the degree of dietary specialization among individuals using a RM GLM by comparing the mean variance within and between individuals (Bearhop et al. 2004). Bearhop et al. (2004) postulate 2 types of generalist populations: first, where all individuals are generalists in their diets; and second, where all individuals are specialists on different prey items, but taken as a whole the population can be described as generalist. One would expect the variation measured sequentially within individuals from the former population of generalists to be approximately equal to the variation found in a sample representative of the whole population, while for the later generalist population, one would expect the variance from sequentially measured individuals to be low compared with the variance derived from a single sample of the population at any one time.

All possible models with 2-way interactions were examined and residuals were examined for lack of fit. Models having the lowest small sample Akaike Information Criterion $\left(\mathrm{AIC}_{\mathrm{c}}\right)$ were selected. GLMs were fitted in S Plus version 6.2 (Insightful Corp.) Other basic statistical analyses were conducted using SPSS version 11.5 (SPSS Inc.). Mean and variance are reported throughout with standard error (SE).

\section{RESULTS}

\section{Fish and invertebrate stable isotope values}

Pelagic species (e.g. capelin, herring, sand lance, redfish) shared similar isotope values that differed significantly from all benthic species (e.g. flounder, plaice, skate), which in turn shared similar $\delta^{13} \mathrm{C}$ $\left(F_{14,45}=17.98 ; \mathrm{p}<0.001\right)$ and $\delta^{15} \mathrm{~N}$ values $\left(F_{14,45}=20.86\right.$; $\mathrm{p}<0.001)$. Pelagic species were more depleted in both carbon and nitrogen relative to benthic species (Fig. 1). The $x$-axis in Fig. 1 represents a continuum of feeding types ranging from highly pelagic (depleted in $\delta^{13} \mathrm{C}$ ) to highly benthic (enriched in $\delta^{13} \mathrm{C}$ ) while the $y$-axis reflects a continuum of trophic levels.

Pelagic and benthic fish also differed significantly in their lipid concentration $\left(F_{11,35}=22.55 ; \mathrm{p}<0.001\right)$; hence, overall energy content also differed (Fig. 2). As predicted, we found a positive relationship between lipid concentration and the $\mathrm{C}: \mathrm{N}$ ratio in the Scotian Shelf prey $\left(F_{1,44}=45.94 ; \mathrm{p}<0.001\right)$. For the expanded dataset of fish and invertebrates in the NW Atlantic, which represents more trophic groups (Fig. 3), there was a significant effect of both $\delta^{15} \mathrm{~N}$ and $\delta^{13} \mathrm{C}$ on C:N ratio (Table 1). Thus, there was a gradient of fat content from low to high with increasing trophic levels, as indicated by $\delta^{15} \mathrm{~N}$, and along the benthic-pelagic continuum, as indicated by $\delta^{13}$ C, e.g. Fig. 2 .

\section{Adult grey seal stable isotope values}

Overall, the isotope signatures of seals were within the range of the prey carbon values (Fig. 3) and were enriched in $\delta^{15} \mathrm{~N}$ by a factor of 2 to $3 \%$ over potential prey, reflecting higher trophic positions.

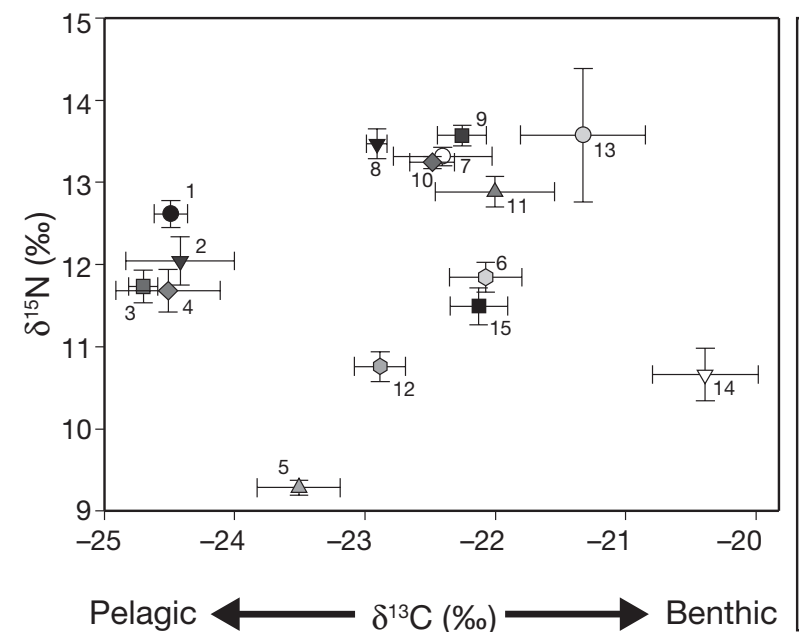

\begin{tabular}{|ll|}
\hline \multicolumn{1}{|c|}{ Pelagic } \\
$\nabla$ & Capelin (1) \\
$\nabla$ & Herring (2) \\
$\square$ & Redfish (3) \\
$\nabla$ & Sandlance (4) \\
$\triangle$ & Squid (5) \\
& \\
& Benthic \\
$\bigcirc$ & Yellowtail flounder (6) \\
$\bigcirc$ & Haddock (7) \\
$\nabla$ & American plaice (8) \\
$\square$ & Snake blenny (9) \\
$\diamond$ & Silver hake (10) \\
$\Delta$ & Thorny skate (11) \\
$\bigcirc$ & Pollock (12) \\
$\bigcirc$ & Atlantic cod (13) \\
$\nabla$ & Snow crab (14) \\
$\square$ & Shrimp (15) \\
\hline
\end{tabular}

Fig. 1. $\delta^{13} \mathrm{C}$ and $\delta^{15} \mathrm{~N}$ values (mean $\pm \mathrm{SE} ; \mathrm{n}=3$ ) for fish and invertebrate species from the Scotian Shelf 


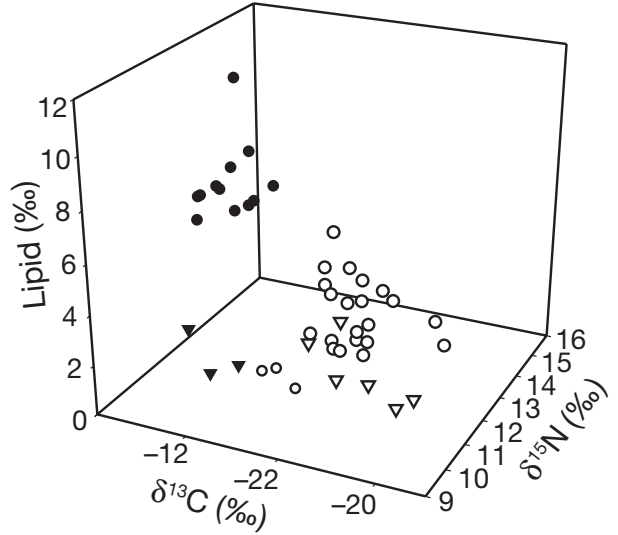

Fig. 2. $\delta^{13} \mathrm{C}$ and $\delta^{15} \mathrm{~N}$ and lipid concentration (\%) in fish (pela-

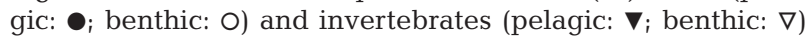
from the Scotian Shelf

\section{Cross-sectional analysis}

In spring and fall cross-sectional samples, neither $\delta^{13} \mathrm{C}\left(F_{1,35}=0.53 ; \mathrm{p}=0.47\right)$ nor $\delta^{15} \mathrm{~N}\left(F_{1,35}=1.88 ; \mathrm{p}=\right.$ $0.18)$ isotope ratios differed significantly among adult males between seasons (Table 2; Fig. 4). Similarly for females, spring and fall samples did not differ in $\delta^{13} \mathrm{C}$ $\left(F_{1,35}=2.42 ; \mathrm{p}=0.13\right)$ or $\delta^{15} \mathrm{~N}\left(F_{1,35}=0.17 ; \mathrm{p}=0.68\right)$. In the spring, males were significantly more enriched in $\delta^{13} \mathrm{C}$ than females $\left(F_{1,39}=9.70 ; \mathrm{p}=0.003\right)$; however, $\delta^{15} \mathrm{~N}$ values were similar $\left(F_{1,31}=0.123 ; \mathrm{p}=0.73\right)$. In the fall, males were also significantly more enriched in $\delta^{13} \mathrm{C}$ than females $\left(F_{1,31}=15.10 ; \mathrm{p}=0.001\right)$ while $\delta^{15} \mathrm{~N}$ values $\left(F_{1,31}=2.66 ; \mathrm{p}=0.11\right)$ were similar.

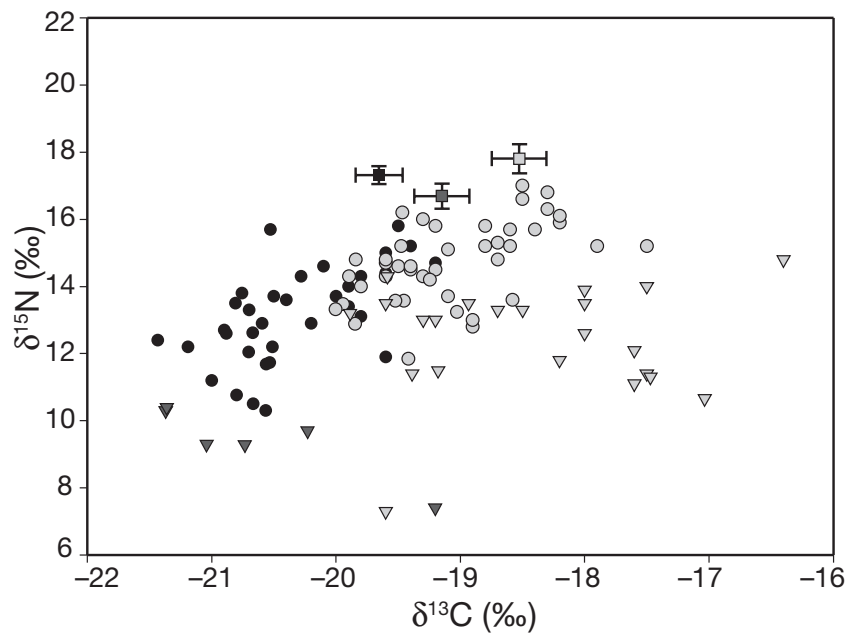

Fig. 3. $\delta^{13} \mathrm{C}$ and $\delta^{15} \mathrm{~N}$ (mean $\pm \mathrm{SE}$ ) for fish species (pelagic: $\bullet$ benthic: $O$ ), invertebrates (pelagic $\nabla$; benthic $\nabla$ ) and seals (juveniles $\boldsymbol{\square}_{\text {; }}$ adult females $\square$; adult males $\square$ ) from the NW Atlantic and Gulf of St Lawrence. Values for fish and invertebrates are from Scotian Shelf (present study), Grand Banks (Sherwood \& Rose 2005) and Gulf of St Lawrence (Lesage et al. 2001). Error bars are $\pm 1 \mathrm{SE}$
Table 1. Results from Generalised Linear Models (GLMs) with stable isotopes and trophic guild as predictors of the fat content in fish $(\mathrm{n}=40)$. Akaike Information Criteria $\left(\mathrm{AIC}_{\mathrm{c}}\right)$, the delta $\operatorname{AIC}_{\mathrm{c}}\left(\Delta_{i}\right)$ and the Akaike weights $\left(w_{i}\right)$. Best fitting models given in bold print

\begin{tabular}{|llcrcc|}
\hline ID & Model & df & $\mathrm{AIC}_{\mathrm{c}}$ & $\Delta_{i}$ & $w_{i}$ \\
\hline $\mathbf{1}$ & $\boldsymbol{\delta}^{\mathbf{1 3}} \mathbf{C}$ & $\mathbf{4 0}$ & $\mathbf{4 . 6 8}$ & $\mathbf{0 . 0 0}$ & $\mathbf{0 . 3 4 1}$ \\
$\mathbf{2}$ & $\boldsymbol{\delta}^{15} \mathbf{N}$ & $\mathbf{4 0}$ & $\mathbf{4 . 8 8}$ & $\mathbf{0 . 2 0}$ & $\mathbf{0 . 3 0 8}$ \\
3 & Trophic guild & 39 & 6.90 & 2.22 & 0.112 \\
4 & $\delta^{13} \mathrm{C}+\delta^{15} \mathrm{~N}$ & 39 & 6.62 & 1.94 & 0.129 \\
5 & $\delta^{13} \mathrm{C}+$ trophic guild & 38 & 8.64 & 3.96 & 0.047 \\
6 & $\delta^{15} \mathrm{~N}+$ trophic guild & 38 & 8.74 & 4.06 & 0.045 \\
7 & $\delta^{13} \mathrm{C}+\delta^{15} \mathrm{~N}+$ trophic guild & 37 & 10.61 & 5.93 & 0.018 \\
\hline
\end{tabular}

On arrival at the breeding colony in January, springsampled males had significantly lower $\delta^{15} \mathrm{~N}$ values than fall-sampled males $\left(F_{1,35}=7.15 ; \mathrm{p}=0.011\right)$, while $\delta^{13} \mathrm{C}$ values were similar $\left(F_{1,35}=0.03 ; \mathrm{p}=0.865\right.$; Fig. 4$)$. By contrast, spring-sampled females had significantly lower $\delta^{13} \mathrm{C}$ values than fall-sampled females $\left(F_{1,35}=7.04\right.$; $\mathrm{p}=0.012)$, but their $\delta^{15} \mathrm{~N}$ values were similar $\left(F_{1,35}=3.34\right.$; $\mathrm{p}=0.076)$. Fall-sampled males were significantly more enriched in $\delta^{13} \mathrm{C}\left(F_{1,31}=17.59 ; \mathrm{p}<0.0001\right)$ and $\delta^{15} \mathrm{~N}$ $\left(F_{1,31}=14.68 ; \mathrm{p}=0.001\right)$ than fall-sampled females (Table 3). Spring-sampled males also were more enriched in $\delta^{15} \mathrm{~N}$ at January recapture than females $\left(F_{1,39}=\right.$ $5.12 ; \mathrm{p}=0.029) ;$ however, $\delta^{13} \mathrm{C}$ values $\left(F_{1,39}=3.65 ; \mathrm{p}=\right.$ 0.064 ) were similar.

\section{Longitudinal analysis}

We used longitudinal samples to evaluate differences between spring and winter and between fall

Table 2. Halichoerus grypus. Mean $\left(\sigma^{2}\right) \delta^{13} \mathrm{C}(\%)$ and $\delta^{15} \mathrm{~N}$ $(\%)$ for adult male and female and juvenile grey seals sampled in spring, fall and winter (mean values from Table 3 presented for adults)

\begin{tabular}{|c|c|c|c|c|c|}
\hline \multirow[t]{2}{*}{ Sample } & \multicolumn{2}{|c|}{ Spring } & \multicolumn{2}{|c|}{ Fall } & Winter \\
\hline & $\delta^{13} \mathrm{C}$ & $\delta^{15} \mathrm{~N}$ & $\delta^{13} \mathrm{C}$ & $\delta^{15} \mathrm{~N}$ & $\delta^{13} \mathrm{C} \quad \delta^{15} \mathrm{~N}$ \\
\hline $\begin{array}{l}\text { Adult males } \\
\text { (spring } n=17 \\
\text { fall } n=19 \text { ) }\end{array}$ & $\begin{array}{r}-15.73 \\
(0.54)\end{array}$ & $\begin{array}{l}17.09 \\
(2.66)\end{array}$ & $\begin{array}{r}-15.89 \\
(0.36)\end{array}$ & $\begin{array}{l}17.79 \\
(1.78)\end{array}$ & $\begin{array}{r}-15.7317 .81 \\
(0.43)(1.64)\end{array}$ \\
\hline $\begin{array}{l}\text { Adult females } \\
\text { (spring } n=21 ; \\
\text { fall } n=15 \text { ) }\end{array}$ & $\begin{array}{r}-16.34 \\
(0.25)\end{array}$ & $\begin{array}{l}16.95 \\
(0.93)\end{array}$ & $\begin{array}{r}-16.58 \\
(0.12)\end{array}$ & $\begin{array}{l}17.08 \\
(1.08)\end{array}$ & $\begin{array}{r}-16.3416 .69 \\
(0.43) \\
(1.23)\end{array}$ \\
\hline $\begin{array}{l}\text { Juvenile males } \\
(\mathrm{n}=15)\end{array}$ & - & - & - & - & $\begin{array}{rr}-16.79 & 17.25 \\
(0.21) & (0.39)\end{array}$ \\
\hline $\begin{array}{l}\text { Juvenile females } \\
(\mathrm{n}=14)\end{array}$ & es & - & - & - & $\begin{array}{r}-16.9517 .42 \\
(0.31)(0.73)\end{array}$ \\
\hline
\end{tabular}




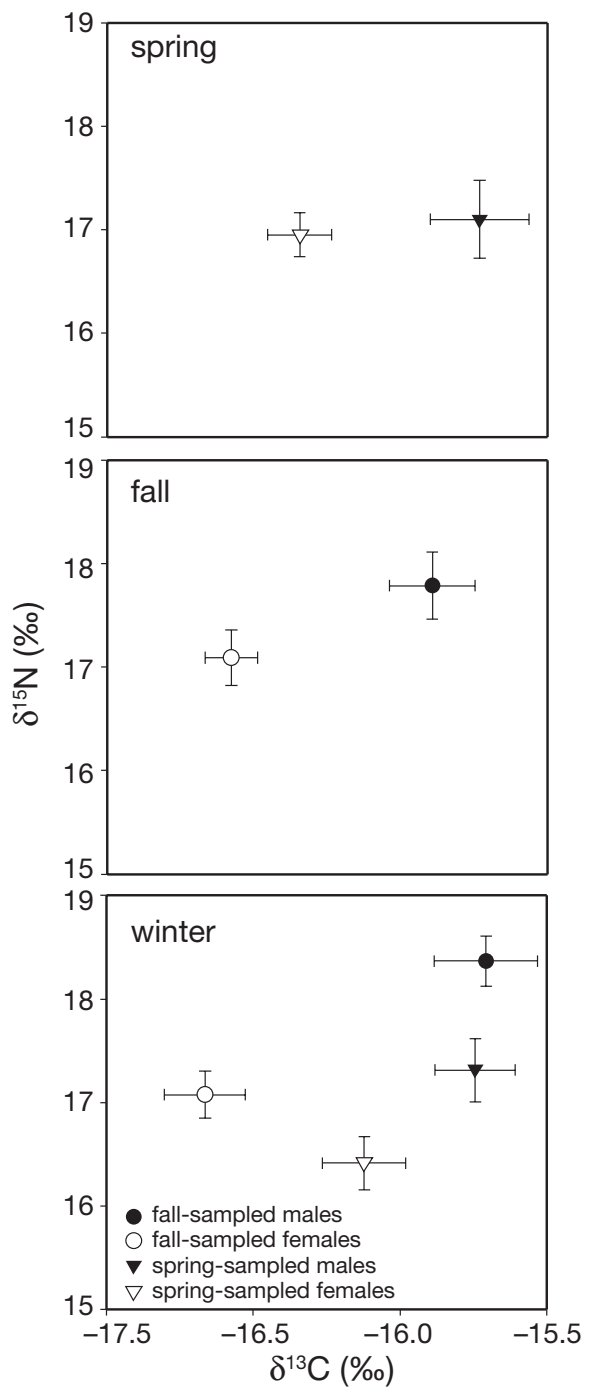

Fig. 4. Halichoerus grypus. $\delta^{13} \mathrm{C}$ and $\delta^{15} \mathrm{~N}$ (mean $\pm \mathrm{SE}$ ) by season for adult male and female grey seals

and winter, both within and between sexes. Spring and winter samples did not differ significantly within males or within females in either $\delta^{13} \mathrm{C}$ (males: $F_{1,18}=$ 0.018; $\mathrm{p}=0.90$ females: $F_{1,20}=1.56 ; \mathrm{p}=0.23$ ) or $\delta^{15} \mathrm{~N}$ (males: $F_{1,18}=0.39 ; \mathrm{p}=0.54$, females: $F_{1,20}=4.22$; $\mathrm{p}=0.053)$. Similarly, fall and winter samples did not differ significantly within males or within females in either $\delta^{13}$ (males: $F_{1,16}=1.50 ; \mathrm{p}=0.24$, females: $F_{1,14}=0.49 ; \mathrm{p}=0.49$ ) or $\delta^{15} \mathrm{~N}$ (males: $F_{1,16}=4.46 ; \mathrm{p}=$ 0.052 , females: $\left.F_{1,14}=0.001 ; \mathrm{p}=0.97\right)$. Males differed significantly from females in $\delta^{13} \mathrm{C}\left(F_{1,38}=8.85 ; \mathrm{p}=\right.$ $0.005)$, but had similar $\delta^{15} \mathrm{~N}$ values in spring and winter $\left(F_{1,38}=2.25 ; \mathrm{p}=0.14\right)$. By contrast, in fall and winter, males differed significantly from females in both $\delta^{13} \mathrm{C}\left(F_{1,30}=21.31 ; \mathrm{p}<0.001\right)$ and $\delta^{15} \mathrm{~N}\left(F_{1,30}=\right.$ 9.32; $\mathrm{p}=0.005$ ).
Table 3. Halichoerus grypus. Mean $\left(\sigma^{2}\right)$ of $\delta^{13} \mathrm{C}(\%)$ and $\delta^{15} \mathrm{~N}$ $(\%)$ in January for spring- and fall-sampled adult male and female grey seals

\begin{tabular}{|llcc|}
\hline \multirow{2}{*}{ Sex } & \multirow{2}{*}{ Season } & \multicolumn{2}{c|}{ January } \\
\cline { 3 - 4 } & & $\delta^{13} \mathrm{C}$ & $\delta^{15} \mathrm{~N}$ \\
\hline \multirow{5}{*}{ Males } & Spring & -15.74 & 17.31 \\
& $(\mathrm{n}=19)$ & $(0.36)$ & $(1.75)$ \\
& Fall & -15.71 & 18.37 \\
& $(\mathrm{n}=17)$ & $(0.53)$ & $(0.99)$ \\
& Spring & -16.12 & 16.41 \\
& $(\mathrm{n}=21)$ & $(0.42)$ & $(1.41)$ \\
& Fall & -16.66 & 17.08 \\
& $(\mathrm{n}=15)$ & $(0.29)$ & $(0.80)$ \\
\hline
\end{tabular}

\section{Juvenile grey seal stable isotope values}

Juvenile males and females sampled in January did not differ in either $\delta^{13} \mathrm{C}\left(F_{1,28}=0.721 ; \mathrm{p}=0.403\right)$ or $\delta^{15} \mathrm{~N}$ values $\left(F_{1,28}=0.359 ; \mathrm{p}=0.554\right)$ (Table 2$)$. However, $\delta^{13} \mathrm{C}$ signatures of juveniles differed significantly from both adult male $\left(F_{1,64}=59.963 ; \mathrm{p}<0.001\right)$ and adult females $\left(F_{1,64}=12.34 ; \mathrm{p}=0.001\right)$ (Figs. $\left.3 \& 5\right)$ whereas $\delta^{15} \mathrm{~N}$ values of juveniles differed significantly from adult females $\left(F_{1,64}=7.11 ; \mathrm{p}=0.010\right)$ but not from adult males $\left(F_{1,64}=3.21 ; \mathrm{p}=0.078\right)$.

\section{Body size, rate of energy accumulation and individual variation}

Adult males were ca. $1.5 \times$ heavier than females in each season (Table 4). Within individuals, there was a significant positive relationship between $\delta^{13} \mathrm{C}$ and body mass $(t=2.54, \mathrm{p}=0.014)$ and a significant sex effect $(t=2.30$, $\mathrm{p}=0.024)$, but no significant interaction between sex and body mass $(t=-0.32, \mathrm{p}=0.75)$ and no effect of season $(t=-1.52, \mathrm{p}=0.13)$. There was also a significant positive effect of mass on $\delta^{15} \mathrm{~N}(t=2.48, \mathrm{p}=0.016)$, but no effect of $\operatorname{sex}(t=1.64, \mathrm{p}=0.11)$ or season $(t=0.86, \mathrm{p}=0.40)$. However, there was a significant interaction between sex and mass $(t=-2.377, \mathrm{p}=0.021)$, indicating that the relationship with mass differed between males and females. This is likely due to the fact that males and females had similar $\delta^{15} \mathrm{~N}$ in both the spring and fall but differed in winter. Further, as the rate of change in mass differed between males and females in both spring $\left(F_{1,27}=4.66 ; \mathrm{p}=0.04\right)$ and fall $\left(F_{1,25}=15.31 ; \mathrm{p}=0.001\right)$, an effect of sex on the relationship between body size and stable isotopes is not unexpected.

We also examined the effect of body mass on stable isotope signatures using cross-sectional data from winter values only, so that juvenile data could also be included in the analysis. There was a significant positive correla- 

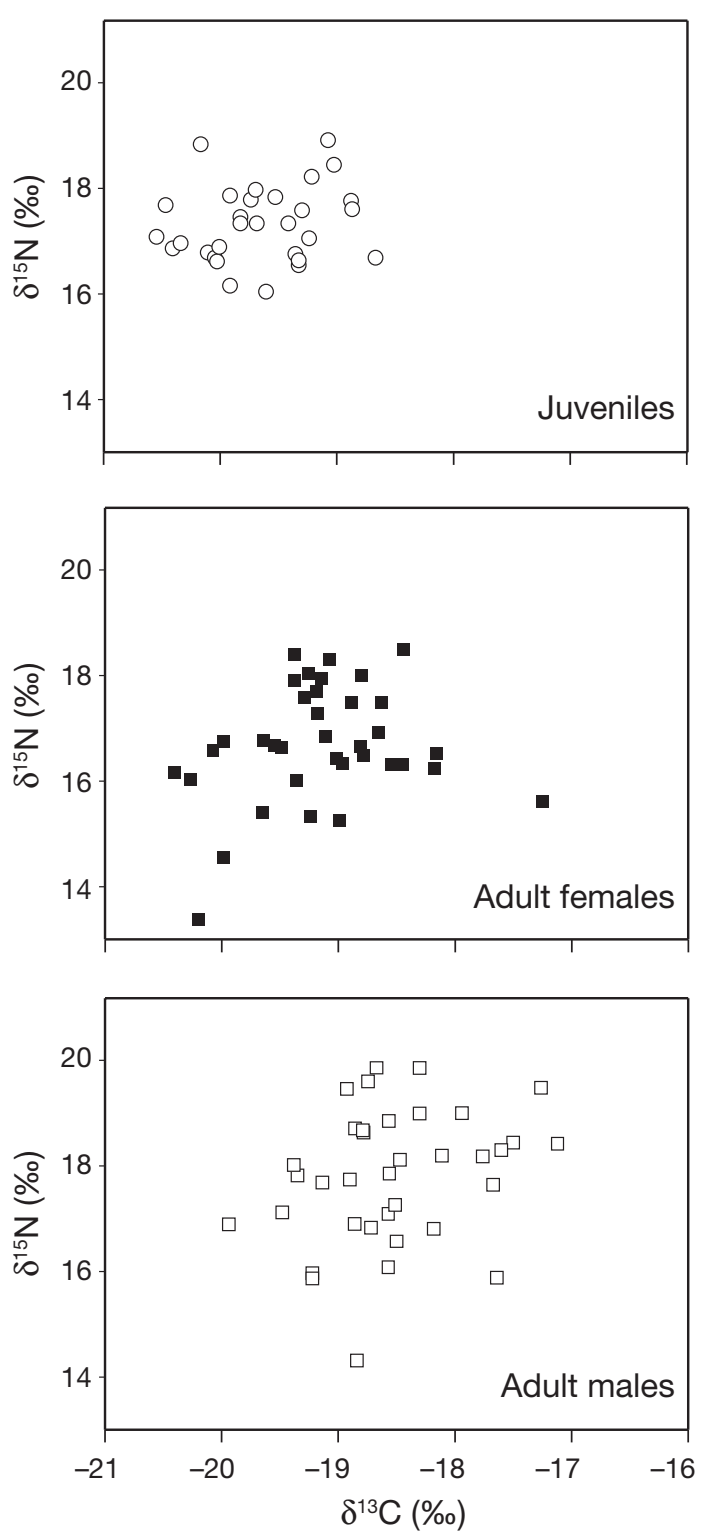

Fig. 5. Halichoerus grypus. $\delta^{13} \mathrm{C}$ and $\delta^{15} \mathrm{~N}$ in individual juvenile, adult female and male grey seals from winter sampling period
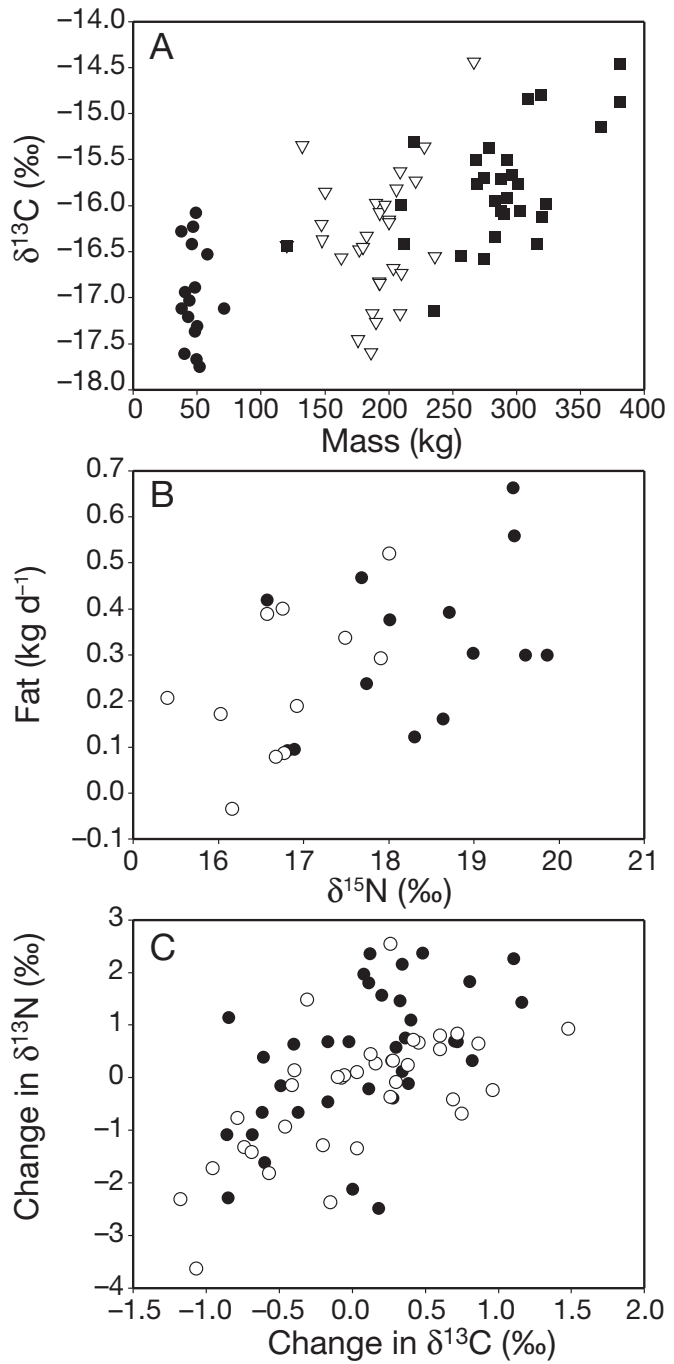

Fig. 6. Halichoerus grypus. (A) Body mass $(\mathrm{kg})$ and $\delta^{13} \mathrm{C}$ in juvenile $(\bullet)$, adult female $(\nabla)$ and adult male $(\bullet)$ grey seals from winter sampling period. (B) $\delta^{15} \mathrm{~N}$ and rate of fat gain $\left(\mathrm{kg} \mathrm{d}^{-1}\right)$ in individual adult female (o) and male (•) grey seals from fall to winter sampling period. (C) Change (recapture value - initial value) in $\delta^{13} \mathrm{C}$ and $\delta^{15} \mathrm{~N}$ from individual

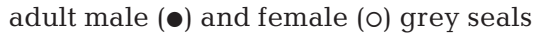

Table 4. Halichoerus grypus. Mean \pm SE mass $(\mathrm{kg})$, fat content $(\%)$, growth rate $\left(\mathrm{kg} \mathrm{d}^{-1}\right)$ and fat accumulation rate $\left(\mathrm{kg}_{\mathrm{fat}} \mathrm{d}^{-1}\right)$ for adult males and females in spring, fall and winter sampling periods

\begin{tabular}{|cllcccc|}
\hline Sample & Season & $\mathrm{n}$ & Mass & Fat & $\begin{array}{c}\text { Mass } \\
\text { gain }\end{array}$ & $\begin{array}{c}\text { Fat } \\
\text { accumulation }\end{array}$ \\
\hline Adult & Spring & 13 & $209.7 \pm 11.4$ & $13.1 \pm 1.6$ & - & - \\
male & Fall & 14 & $238.0 \pm 8.1$ & $22.4 \pm 1.6$ & $0.549 \pm 0.067$ & $0.320 \pm 0.046$ \\
& Winter & 25 & $296.0 \pm 7.9$ & $28.7 \pm 1.2$ & & - \\
Adult & Spring & 15 & $135.0 \pm 6.2$ & $14.6 \pm 1.4$ & - & - \\
female & Fall & 11 & $165.9 \pm 6.6$ & $26.0 \pm 2.3$ & $0.191 \pm 0.064$ & $0.240 \pm 0.050$ \\
& Winter & 23 & $196.8 \pm 5.5$ & $34.6 \pm 1.8$ & & - \\
Juveniles & Winter & 16 & $47.7 \pm 2.1$ & - & - & \\
\hline
\end{tabular}

tion (Fig. 6) between body mass and $\delta^{13} \mathrm{C}$ $\left(F_{1,73}=11.26 ; \mathrm{p}=0.001\right)$, with no effect of age class $\left(F_{1,73}=1.12 ; \mathrm{p}=0.29\right)$ or sex $\left(F_{1,73}=0.049 ; \mathrm{p}=0.83\right)$. Body size in juveniles ranged from 37.5 to $71.0 \mathrm{~kg}$. However, in contrast to adults, we found a significant negative relationship between juvenile body mass and $\delta^{15} \mathrm{~N}\left(F_{1,15}=6.77\right.$; $\mathrm{p}=0.02$ ).

There was no relationship between the carbon signature and either the rate of energy accumulation $\left(F_{1,24}=1.32 ; \mathrm{p}=\right.$ $0.26)$ or fat content $\left(F_{1,24}=0.40 ; \mathrm{p}=0.53\right)$ of seals. However, there was a positive 
Table 5. Halichoerus grypus. Between population level (population) and within population level (within) variance $\left(\sigma^{2}\right)$ for $\delta^{13} \mathrm{C}(\%)$ and $\delta^{15} \mathrm{~N}(\%)$ of adult male and female seals in spring, fall and winter sampling periods. Winter values, as well as the within population variance from repeated measures analysis for spring-sampled (spring) and fall-sampled (fall) individuals are shown separately

\begin{tabular}{|c|c|c|c|c|c|c|c|c|c|}
\hline \multirow[t]{2}{*}{ Sex } & & \multicolumn{2}{|c|}{ Spring } & \multicolumn{2}{|c|}{ Fall } & \multicolumn{2}{|c|}{$\begin{array}{c}\text { Winter } \\
\text { (spring) }\end{array}$} & \multicolumn{2}{|c|}{$\begin{array}{c}\text { Winter } \\
\text { (fall) }\end{array}$} \\
\hline & & $\delta^{13} \mathrm{C}$ & $\delta^{15} \mathrm{~N}$ & $\delta^{13} \mathrm{C}$ & $\delta^{15} \mathrm{~N}$ & $\delta^{13} \mathrm{C}$ & $\delta^{15} \mathrm{~N}$ & $\delta^{13} \mathrm{C}$ & $\delta^{15} \mathrm{~N}$ \\
\hline \multirow[t]{3}{*}{ Male } & Population & 0.53 & 2.66 & 0.35 & 1.78 & 0.36 & 1.75 & 0.53 & 0.99 \\
\hline & Within-spring & 0.35 & 1.14 & - & - & 0.35 & 1.14 & - & - \\
\hline & Within-fall & - & - & 0.24 & 0.68 & - & - & 0.24 & 0.68 \\
\hline \multirow[t]{3}{*}{ Female } & Population & 0.25 & 0.93 & 0.12 & 1.08 & 0.42 & 1.41 & 0.29 & 0.80 \\
\hline & Within-spring & 0.001 & 0.39 & - & - & 0.001 & 0.39 & - & - \\
\hline & Within-fall & - & - & 0.09 & 0.26 & - & - & 0.09 & 0.26 \\
\hline
\end{tabular}

effect of $\delta^{15} \mathrm{~N}\left(F_{1,24}=5.69 ; \mathrm{p}=0.02\right)$ on the rate of fat gain, but no sex effect $\left(F_{1.24}=0.27 ; \mathrm{p}=0.61\right)$ (Fig. 6). There was also a positive relationship between $\delta^{15} \mathrm{~N}$ and the winter percent body fat content in males $\left(F_{1,13}=\right.$ $7.46 ; \mathrm{p}=0.02)$, although, this was not the case for females $\left(F_{1,10}=1.25 ; \mathrm{p}=0.29\right)$.

Individuals differed by an average of 0.49 (abs \%o) in $\delta^{13} \mathrm{C}$ (range: -1.07 to $+2.13 \%$ ) and by 0.99 (abs \%o) in $\delta^{15} \mathrm{~N}$ (range: -3.63 to +2.37 ) between initial and final capture. There was positive correlation between initial and final values of carbon (Pearson's $r=0.59, \mathrm{p}<0.001$, $\mathrm{n}=72$ ) and nitrogen (Pearson's $\mathrm{r}=0.50, \mathrm{p}<0.001, \mathrm{n}=$ 72 ). Given that the sampling interval exceeded the isotope turnover time, initial values should not have influenced final values (Kurle \& Worthy 2001, Lesage et al. 2001). Therefore, on average, changes in isotope values within individuals were relatively small. There was a positive correlation between the change in $\delta^{13} \mathrm{C}$ and the change in $\delta^{15} \mathrm{~N}\left(F_{1,53}=18.44 ; \mathrm{p}<0.001\right.$; Fig. 6). There was no effect of sex $\left(\delta^{13} \mathrm{C}: F_{1,53}=0.31 ; \mathrm{p}=0.58\right.$; $\left.\delta^{15} \mathrm{~N}: F_{1,53}=2.57, \mathrm{p}=0.11\right)$ or sampling season $\left(\delta^{13} \mathrm{C}\right.$ : $F_{1,53}=0.52 ; \mathrm{p}=0.48, \delta^{15} \mathrm{~N}: F_{1,53}=1.25 ; \mathrm{p}=0.27$ ) on this relationship. Conversely, the temporal change in isotope values within individuals had no significant effect on growth rate, whether calculated as a change in overall mass $\left(\delta^{13} \mathrm{C}: F_{1,53}=0.58 ; \mathrm{p}=0.45 ; \delta^{15} \mathrm{~N}: F_{1,53}=\right.$ $0.41 ; \mathrm{p}=0.53)$ or a change in the amount of fat $\left(\delta^{13} \mathrm{C}\right.$ : $\left.F_{1,53}=2.13 ; \mathrm{p}=0.15 ; \delta^{15} \mathrm{~N}: F_{1,53}=0.23 ; \mathrm{p}=0.64\right)$.

\section{Niche breadth}

Males $\left(\delta^{13} \mathrm{C}: \sigma^{2}=0.43 \%\right.$; $\delta^{15} \mathrm{~N}: \sigma^{2}=1.98 \%$ o) had approximately a $1.5 \times$ greater niche breadth than females $\left(\delta^{13} \mathrm{C}: \sigma^{2}=0.32 \%\right.$; $\delta^{15} \mathrm{~N}: \sigma^{2}=1.11 \%$ ), whether considering $\delta^{13} \mathrm{C}\left(F_{1,142}=38.02 ; \mathrm{p}<0.001\right)$ or $\delta^{15} \mathrm{~N}$ $\left(F_{1,142}=13.69 ; \mathrm{p}<0.001 ;\right.$ Table 5$)$. This difference was observed in both spring and fall samples. Relative to adults (see winter values, Table 2 ) niche breadth for juvenile seals $\left(\delta^{13} \mathrm{C}: \sigma^{2}=\right.$ $0.25 \%$; $\delta^{15} \mathrm{~N}: \sigma^{2}=0.52 \%$ ) was roughly half for both $\delta^{13} \mathrm{C}\left(F_{2,101}=28.05 ; \mathrm{p}<\right.$ $0.001)$ and $\delta^{15} \mathrm{~N}\left(F_{2,101}=9.69 ; \mathrm{p}<0.001\right)$.

Within-population variance of $\delta^{13} \mathrm{C}$ (males: $F_{1,18}=0.018 ; \mathrm{p}=0.90$, females: $F_{1,20}=1.56 ; \mathrm{p}=0.23$ ) and $\delta^{15} \mathrm{~N}$ (males: $F_{1,18}=0.39 ; \mathrm{p}=0.54$, females: $F_{1,20}=4.22$; $\mathrm{p}=0.053$ ) was less than the between population variance (i.e. no significant within-subject effects; Table 5) for spring- and winter-sampled seals. Similar results were found in seal samples in fall and winter for $\delta^{13} \mathrm{C}$ (males: $F_{1,16}=$ 1.50; $\mathrm{p}=0.24$, females: $F_{1,14}=0.49 ; \mathrm{p}=$ 0.49 ) and $\delta^{15} \mathrm{~N}$ (males: $F_{1,16}=4.46 ; \mathrm{p}=$ 0.052 , females: $F_{1,14}=0.001 ; \mathrm{p}=0.97$ ). Thus, diets of individual seals changed less over time relative to the total observed dietary space of grey seals.

\section{DISCUSSION}

Stable isotope values of fishes and invertebrates from the Scotian Shelf suggest that taxa are organized along a clearly defined axis where pelagic organisms are more depleted in both $\delta^{13} \mathrm{C}$ and $\delta^{15} \mathrm{~N}$ and benthic organisms are more enriched in $\delta^{13} \mathrm{C}$ and $\delta^{15} \mathrm{~N}$. On average, invertebrates were $3 \%$ lower than fish in $\delta^{15} \mathrm{~N}$ in each trophic guild, thereby reflecting trophic positions of consumers. Sherwood \& Rose (2005) and Davenport \& Bax (2002) also found that the baseline of $\delta^{15} \mathrm{~N}$ is more elevated for benthic systems, resulting in higher overall $\delta^{15} \mathrm{~N}$ values for equivalent trophic positions of pelagic or benthic piscivores. Consequently, a $\delta^{15} \mathrm{~N}$ signature must always be interpreted in the context of a corresponding $\delta^{13} \mathrm{C}$ signature. Using the ratio of $\mathrm{C}: \mathrm{N}$ as a proxy for lipid concentration, we found that, on average, pelagic fish at the highest trophic levels have high concentrations of lipid while benthic fish at the lowest trophic level have low concentrations of lipid.

Overall, the carbon isotope signatures of seals were contained within the range of the prey carbon axis (Fig. 3) and were enriched in $\delta^{15} \mathrm{~N}$ by 2 to $3 \%$ over potential prey, reflecting their higher trophic level. The mean differences in $\delta^{13} \mathrm{C}$ and $\delta^{15} \mathrm{~N}$ values suggests that adult females fed on a greater proportion of pelagic prey whereas adult males consumed a higher proportion of benthic species. Juveniles had a carbon signature even more deplete than adult female seals, suggesting that their carbon was derived primarily from pelagic sources. Thus, inferences about diets of adult males and females are consistent with sex- 
specific seasonal differences in diving behaviour (Beck et al. 2003b). Indeed, the sex differences indicated by stable isotopes are similar, both in a qualitative (Beck et al. 2005) and quantitative (Bowen et al. 2006) manner, to the results of fatty acid analyses. Males and females had similar $\delta^{15} \mathrm{~N}$ in the spring and fall but differed in winter samples. As the baseline nitrogen signature of prey changes relative to the position on the carbon axis (our Figs. $1 \&$ \&; Davenport \& Bax 2002 , Sherwood \& Rose 2005), overlap in $\delta^{15} \mathrm{~N}$ signatures of seals with different $\delta^{13} \mathrm{C}$ signatures does not necessarily imply convergent diets. The results here suggest that, overall, adult males and females were segregated with respect to diet, as were juveniles, whether it is from consuming different prey items or different proportions of the same prey items. This segregation would operate along 2 lines, namely the main carbon pool (pelagic/benthic systems) from which energy is derived, and the trophic position within that system. Thus, it is likely that this segregation in diet is a manifestation of spatial segregation within the water column or geographic segregation (Breed et al. 2006) and this may act to reduce intraspecific competition. Similar results in spatial segregation and inferred dietary segregation have been found for other pinnipeds (Le Boeuf et al. 1993, 2000, Field et al. 2005) and seabirds (Weimerskirch et al. 1997, González-Solis et al. 2000).

Sex differences remained significant across seasons. Overall, males were more enriched in $\delta^{13} \mathrm{C}$ than females in all seasons (Fig. 4). For $\delta^{15} \mathrm{~N}$, values were similar in the spring and fall, but were more enriched by winter in males. Within each sex, there were no significant differences in isotope values between spring and fall. However, in the winter there were significant differences related to when seals were initially sampled. Using satellite telemetry, Austin et al. (2004) found that those individuals captured on Sable during the spring moult were more likely to be long-ranging directed travelers subsequently fanning out across the Scotian Shelf and the Gulf of St Lawrence. In contrast, the majority of seals captured and instrumented in the fall tended to be residents, primarily foraging near Sable Island. Sable Island Bank is a relatively shallow (50 to $100 \mathrm{~m}$ ) sandy region, which is a habitat for species such as sand lance and capelin (Zwanenburg et al. 2002). The remainder of the shelf and shelf edges have greater habitat complexity and greater depth ranges than the shallow banks. Consequently, a different array of fish species are found there (Zwanenburg et al. 2002). Furthermore, some prey species eaten by grey seals also exhibit seasonal variation in distribution and abundance (Bowen et al. 2006). These seasonal changes in distribution but also seasonal changes in prey presumably both contribute to differ- ences in the final winter stable isotope values for the spring and fall sampled individuals.

Dietary niche breadth is a metric for measuring the degree of specialization. Based on the variance in stable isotope values, dietary niche breadth was ca. $1.5 \times$ greater in males than in females. On average, adult grey seals had $2 \times$ higher niche breadth than juveniles. It is often assumed that juveniles are limited in their foraging ability relative to adults due to lack of experience and cognitive ability and that they presumably have access to fewer or different types of prey, e.g. Baker \& Donohue (2000), Noren et al. (2005). In terrestrial systems of sympatric predators, there is a positive relationship between increasing body size and niche breadth (Radloff \& du Toit 2004) and the dietary niche of smaller carnivores is nested within that of larger carnivores (Sinclair et al. 2003).

There were no significant changes in niche breadth among adults between seasons, although sample sizes were relatively small and more data is needed to confirm this conclusion. However, our results indicated that individual grey seals are relative specialists as diets change less for individuals over time relative to the total observed dietary space of the population. On average, between initial capture in the spring or fall, and recapture in the winter, individuals varied by $<0.5 \%$ in $\delta^{13} \mathrm{C}$ and $<1 \%$ in $\delta^{15} \mathrm{~N}$ signatures. There was no difference between sexes in the degree of change, nor was there a consistent pattern in the direction of change among individuals. However, there was a high degree of individual variation in signatures (Fig. 5). This is not entirely unexpected as foraging behaviour in particular, as well as movement and feeding frequency, have been found to be highly variable among individual grey seals, although a direct link with diet has not yet been made (Beck et al. 2003b, Austin et al. 2004). Studies estimating diet for individuals of other species of marine mammals also demonstrate a high degree of variation (reviewed in Bowen et al. 2002a), although, with the exception of sea otters (Estes et al. 2003), temporal consistency within individuals has not yet been studied.

Sex differences in foraging behaviour of pinnipeds are assumed to reflect differences in sex-specific costs of reproduction, body size or competitive abilities. To that effect, 2 interesting results emerge from the stable isotope data. The first is that there is a high degree of overlap in diet across sex and age-class and a correlation for both $\delta^{13} \mathrm{C}$ and $\delta^{15} \mathrm{~N}$ signatures with body size across all age classes; that is, diet changes with body mass. Our data suggest a shift from more pelagic to more benthic diets as body size increases. It is probable that $\delta^{15} \mathrm{~N}$ of seals is shifting due to a change in the main $\delta^{13} \mathrm{C}$ source of the diet, paralleling 
trends of the prey axis. Indeed, within individuals there is a positive correlation between $\delta^{13} \mathrm{C}$ and $\delta^{15} \mathrm{~N}$. The second result is that seals are achieving higher rates of fat gain on diets which are at a higher trophic level. An examination of potential prey data suggest that this is possibly a higher quality diet, i.e. more energy rich. The correlation of stable isotope values, or diet, with body size and rate of energy gain suggests that energetics are a parsimonious, underlying mechanism in diet selection and ontogenetic diet changes in grey seals.

In adults, both sexes increase their rate of energy storage during the 3 mo prior to reproduction, and it has been assumed that they may forage more selectively on a few high-quality prey species during the fall/early winter period (Beck et al. 2005). Results of the stable isotope analysis suggest that higher rates of energy gain are indeed obtained through different diets. However, based on the variance ratio test of stable isotope values between spring, fall and winter, diets appear to be just as relatively diverse in all those seasons. However, we found a positive relationship between the rate of fat accumulation $\left(\mathrm{kg} \mathrm{d}^{-1}\right)$ over the fall period and $\delta^{15} \mathrm{~N}$, such that seals with the highest rates of fat gain had higher $\delta^{15} \mathrm{~N}$ values. There was also a positive relationship between the total amount of fat $(\mathrm{kg})$ or the percent body fat (\%) and diet only in males. Based on the stable isotope values and prey quality, this suggests that seals are likely to have been consuming prey of higher energy density, since both benthic and pelagic fish at higher trophic positions have higher fat concentration of prey. There was no correlation between energy gain and the $\delta^{13} \mathrm{C}$ signature, suggesting that benthic-pelagic segregation is not important but relative trophic position is. Thus, prey selection appears to affect the efficiency with which energy is gained in both males and females.

Lipid or energy concentration is simply one consideration in diet selection and overall energy gain of a predator. Other considerations include availability of prey and the subsequent costs associated with pursuit, capture, handling and digestion. In fish, diet shifts with increasing body size are thought to reflect the limiting factor of gap size and the increasing foraging cost of consuming relatively smaller prey (Sherwood et al. 2002). That is, a shift in diet is made when the costs outweigh the benefits of feeding on a particular prey or prey-size class (e.g. Jones et al. 1994, Sherwood et al. 2002). This, in turn, leads to lower energetic demands, with respect to minimizing time and activity costs spent in burst swimming and pursuit of prey (Sherwood et al. 2002). Typically, this diet switch is made in the direction of larger prey, but the underlying operative is decreased foraging costs. Therefore, with respect to ontogeny and body size differences in diets for greys seals, one hypothesis is that diet shifts towards a larger fraction of benthic prey are made to reduce foraging costs thereby maximizing gains, since these are such a large fraction of the energy budget. Foraging costs are likely reduced on more sedentary, benthic prey despite their lower quality. The caveat here is that the capacity to digest this prey comes with larger body size (Ginnett \& Demment 1997).

Stable isotopes indicate representative trophic relationships related to functional patterns of feeding (i.e. benthic-pelagic, higher-lower trophic level) rather than an explicit taxonomic description of diet. In certain cases, functional feeding patterns provide more meaningful insight into overall food web properties and dynamics (e.g. Williams \& Martinez 2000). Through stable isotope analysis we found mean differences in diet between adults and juveniles and between adult males and females. The divergence among these groups lends support to the idea of dietary segregation in grey seals. The lack of sex differences in the diet of juveniles is probably indicative of the lack of dimorphism at that stage. Therefore, it is unlikely that sex dimorphism is an important factor until male and female body sizes diverge dramatically. However, the data were characterized by a high degree of variation and, in fact, grey seals were found to be relative specialists in their diets. Although we can make general inferences based on age-class or sex, we essentially see a continuum of diets (along the prey axis) across individuals, where overlap between age-class and sex groups is correlated with body size. The relative trophic position of the diet was seen to affect the rate or efficiency with which energy was stored in both adult males and females, and in the case of males, diet had an influence on total fat content. However, position along the $\delta^{13} \mathrm{C}$ axis, or degree of benthic feeding, had no effect on energy storage. Thus, individuals are achieving similar endpoints by exploiting different energy sources. It has previously been found, as well, that mean differences between sexes in foraging behaviour of grey seals are marked by a high degree of individual variability. These 2 results lend further support for the idea of multiple foraging strategies with convergent success (Bolnick et al. 2003, Estes et al. 2003).

Acknowledgements. We thank Debbie Austin, Carrie Beck, Daryl Boness, Susanne Budge, Shelley Lang, Damian Lidgard and Jim McMillan for their assistance in the field. We also thank Gerry Forbes, Officer-in-Charge of the Atmospheric Environmental Service, for logistical support on Sable Island. Wade Blanchard and Debbie Austin provided valuable advice on statistical analysis. Debbie Austin and 2 anonymous referees provided helpful comments on earlier drafts of the manuscript. This study was supported by Natural Sciences and Engineering Research Council (NSERC) Canada research 
grants to W.D.B. and S.J.I. and by the Department of Fisheries and Oceans, Canada. All procedures used on grey seals in this study were in accordance with the principles and guidelines of the Canadian Council on Animal Care.

\section{LITERATURE CITED}

Austin D, Bowen WD, McMillan JI (2004) Intraspecific variation in movement patterns: modeling individual behaviour in a large marine predator. Oikos 105:15-30

Austin D, Bowen WD, McMillan JI, Boness DJ (2006a) Stomach temperature telemetry reveals temporal patterns of foraging success in a free-ranging marine mammal. J Anim Ecol 75:408-420

Austin D, Bowen WD, McMillan JI, Iverson SJ (2006b) Consequences of behaviour on foraging success: linking movement, diving and habitat to feeding in a large marine predator. Ecology 87:3095-3108

Baker JD, Donohue MJ (2000) Ontogeny of swimming and diving in northern fur seal (Callorhinus ursinus) pups. Can J Zool 78:100-109

Bearhop S, Adams CE, Waldron S, Fuller RA, Macleod H (2004) Determining trophic niche width: a novel approach using stable isotope analysis. J Anim Ecol 73:1007-1012

Beck CA, Bowen WD, Iverson SJ (2003a) Sex differences in the seasonal patterns of energy storage and expenditure in a phocid seal. J Anim Ecol 72:280-291

Beck CA, Bowen WD, McMillan JI, Iverson SJ (2003b) Sex differences in diving at multiple temporal scales in a sizedimorphic capital breeder. J Anim Ecol 72:979-993

Beck CA, Iverson SJ, Bowen WD (2005) Blubber fatty acids of gray seals reveal sex differences in the diet of a sizedimorphic marine carnivore. Can J Zool 83:377-388

Bolnick DI, Svanback R, Fordyce JA, Yang LH, Davis JM, Hulsey CD, Forister ML (2003) The ecology of individuals: incidence and implications of individual specialization. Am Nat 1:1-28

Bowen WD, Siniff DB (1999) Distribution, population biology, and feeding ecology of marine mammals. In: Renolds III JE, Rommel SA (eds) Biology of marine mammals. Smithsonian Institution Press, Washington, DC, p 423-484

Bowen WD, Oftedal OT, Boness DJ (1992) Mass and energy transfer during lactation in a small phocid, the harbor seal (Phoca vitulina). Physiol Zool 65:844-866

Bowen WD, Read AJ, Estes JA (2002) Feeding ecology. In: Hoelzel AR (ed) Marine mammal biology: an evolutionary approach. Blackwell Science, Oxford

Bowen WD, Beck CA, Iverson SJ, Austin D, McMillan JI (2006) Linking predator foraging behaviour and diet with variability in continental shelf ecosystems: grey seals of eastern Canada. In: Boyd I, Wanless S, Camphuysen CJ (eds) Top predators in marine ecosystems. Their role in monitoring and management. Cambridge University Press, Cambridge, p 63-81

Breed GA, Bowen, WD, McMillan, JI, Leonard, ML (2006) Sexual segregation of seasonal foraging habitats in a nonmigratory marine mammal. Proc R Soc Lond B 273: 2319-2326

Budge SM, Iverson SJ, Bowen WD, Ackman RG (2002) Among- and within-species variability in fatty acid signatures of marine fish and invertebrates on the Scotian Shelf, Georges Bank, and southern Gulf of St. Lawrence. Can J Fish Aquat Sci 59:886-898

Carbone C, Mace GM, Roberts SG, Macdonald DW (1999) Energetic constraints on the diet of terrestrial carnivores. Nature 402:286-288
Chase JM (1999) Food web effects of prey size refugia: variable interactions and alternative stable equilibria. Am Nat 154: $559-570$

Clarke J, Manly B, Kerry K, Gardner H, Franchi E, Corsolini S, Focardi S (1998) Sex differences in Adelie penguin foraging strategies. Polar Biol 20:248-258

Cohen JE, Pimm SL, Yodzis P, Saldaña (1993) Body sizes of animal predators and animal prey in food webs. J Anim Ecol 62:67-78

Davenport SR, Bax NJ (2002) A trophic study of a marine ecosystem off southeastern Australia using stable isotopes of carbon and nitrogen. Can J Fish Aquat Sci 59:514-530

Estes JA, Riedman ML, Staedler MM, Tinker MT, Lyon BE (2003) Individual variation in prey selection by sea otters: patterns, causes and implications. J Anim Ecol 72:144-155

Field IC, Bradshaw CJA, Burton HR, Sumner MD, Hindell MA (2005) Resource partitioning through oceanic segregation of foraging juvenile southern elephant seals (Mirounga leonina). Behav Ecol 142:127-135

Ginnett TF, Demment MW (1997) Sex differences in giraffe foraging behaviour at two spatial scales. Oecologia 110: 291-300

Gittleman JL (1985) Carnivore body size: ecological and taxonomic correlates. Oecologia 67:540-554

González-Solís J, Croxall JP, Wood AG (2000) Foraging partitioning between giant petrels Macronectes spp. and its relationship with breeding population changes at Bird Island, South Georgia. Mar Ecol Prog Ser 204:279-288

Hobson KA, Welch HE (1992) Determination of trophic relationships within a high Arctic marine food web using $\delta^{13} \mathrm{C}$ and $\delta^{15} \mathrm{~N}$ analysis. Mar Ecol Prog Ser 84:9-18

Hobson KA, Piatt JF, Pitocchelli J (1994) Using stable isotopes to determine seabird trophic relationships. J Anim Ecol 63:786-798

Hobson KA, Schell DM, Renouf D, Noseworthy E (1996) Stable carbon and nitrogen isotopic fractionation between diet and tissues of captive seals: implications for dietary reconstructions involving marine mammals. Can J Fish Aquat Sci 53:528-533

Iverson SJ, Lang SL, Cooper MH (2001) Comparison of the Bligh and Dyer and Folch methods for total lipid determination in a broad range of marine tissue. Lipids 36 : 1283-1287

Jones MS, Goettl JP Jr, Flickinger SA (1994) Changes in walleye food habits and growth following a rainbow smelt introduction. N Am J Fish Manag 14:409-414

Kurle CM, Worthy GAJ (2001) Stable isotope assessment of temporal and geographic differences in feeding ecology of northern fur seals (Callorhinus ursinus) and their prey. Oecologia 126:254-265

Le Boeuf BJ, Crocker DE, Blackwell SB, Morris PA, Thorson PH (1993) Sex differences in diving and foraging behaviour of northern elephant seals. Symp Zool Soc Lond 66:149-178

Le Boeuf, BJ, Crocker, DE, Costa, DP, Blackwell, SB, Webb, PM, Houser, DS (2000) Foraging ecology of northern elephant seals. Ecol Monogr 70:353-382

Lesage V, Hammill MO, Kovacs KM (2001) Marine mammals and the community structure of the Estuary and Gulf of St Lawrence, Canada: evidence from stable isotope analysis. Mar Ecol Prog Ser 210:203-221

Lewis S, Benvenuti S, Dall'Antonia L, Griffiths R, Money L, Sherratt TN, Wanless S, Hamer KC (2002) Sex-specific foraging behaviour in a monomorphic seabird. Proc R Soc Lond B 269:1687-1693

McConnaughey T, McRoy CP (1979) Food web structure and the fractionation of carbon isotopes in the Bering Sea. Mar Biol 53:257-262 
Memmott J, Martinez ND, Cohen JE (2000) Predators, parasitoids and pathogens: species richness, trophic generality and body sizes in a natural food web. J Anim Ecol 69:1-15

Noren SR, Iverson SJ, Boness DJ (2005) Development of the blood and muscle oxygen stores in gray seals (Halichoerus grypus): implications for juvenile diving capacity and the necessity of a terrestrial postweaning fast. Physiol Biochem Zool 78:482-490

Post DM (2002) Using stable isotopes to estimate trophic position: models, methods and assumptions. Ecology 83: 703-718

Radloff FGT, du Toit JT (2004) Large predators and their prey in a southern African savanna: a predator's size determines its prey size range. J Anim Ecol 73:410-423

Scott WB, Scott MG (1988) Atlantic fishes of Canada. Can Bull Fish Aquat Sci 219

Sherwood GD, Rose GA (2005) Stable isotope analysis of some representative fish and invertebrates of the Newfoundland and Labrador continental shelf food web. Estuar Coast Shelf Sci 63:537-549

Sherwood GD, Pazzia I, Moeser A, Hontela A, Rasmussen JB (2002) Shifting gears: enzymatic evidence for the energetic advantage of switching diet in wild-living fish. Can J Fish Aquat Sci 59:229-241

Editorial responsibility: Howard Browman (Associate Editorin-Chief), Storebø, Norway
Sih A, Christensen B (2001) Optimal diet theory: When does it work, and when and why does it fail? Anim Behav 61: 379-390

Sinclair ARE, Mduma S, Brashares JS (2003) Patterns of predation in a diverse predator-prey system. Nature 425: 288-290

Tieszen, LL, Boutton, TW, Tesdahl, KG, Slade, NA (1983) Fractionation and turnover of stable carbon isotopes in animal tissues: implications for $\delta^{13} \mathrm{C}$ analysis of diet. Oecologia 57:32-37

Weimerskirch H, Wilson RP, Lys P (1997) Activity pattern of foraging in the wandering albatross: a marine predator with two modes of prey searching. Mar Ecol Prog Ser 151: 245-254

Williams RJ, Martinez ND (2000) Simple rules yield complex food webs. Nature 404:180-183

Woodward G, Hildrew AG (2002) Body-size determinants of niche overlap and intraguild predation within a complex food web. J Anim Ecol 71:1063-1074

Zwanenburg KCT, Bowen WD, Bundy A, Drinkwater K, Frank K, O'Boyle R, Sameoto D, Sinclair M (2002) Decadal changes in the Scotian Shelf ecosystem: large marine ecosystem. In: Sherman K, Skjoldal HR (eds) Large marine ecosystems of the North Atlantic: changing states and sustainability. Elsevier Science, Amsterdam, p 105-150

Submitted: June 12, 2006; Accepted: November 19, 2006 Proofs received from author(s): May 17, 2007 